\title{
Neoklasik iktisat: Anaakım mı, Ortodoks mu?
}

\author{
Neoclassical Economics: Is it Mainstream or Orthodox?
}

\author{
Dr. Öğr. Üyesi Hüsnü Bilir ${ }^{1}$
}

Başvuru Tarihi: 28.03.2018

Kabul Tarihi: 13.03 .2019

Öz

İktisat literatüründe neoklasik iktisadı tanımlamak üzere 'ortodoks', 'anaakım', 'geleneksel', 'dominant', 'modern', 'geçerli' veya 'standart' gibi kavramlar kullanılmaktadır. Ancak kullanılan bu kavramlar farklı anlamlara sahiptir. Kaldı ki bu sıfatların aynı anlamda kullanıldığın kabul etsek bile, iktisat disiplini evrilen bir yapıya sahiptir. Bu bağlamda 'ortodoks' ve 'anaakım' gibi kavramlar da zaman içinde değişikliğe uğramaktadır. Dolayısıyla örneğin bugün anaakım olan bir düşünce okulu veya yaklaşım gelecek dönemde anaakım dışında kalabilmekte veya bugün anaakım olmayan bir düşünce okulu gelecek dönemde anaakıma dâhil olabilmektedir. Aynı șekilde disiplinin ortodoksisi de zaman içerisinde değişebilmektedir. Bu çalışmanın amacı, neoklasik iktisadın günümüzde iktisat disiplinine hâkim olan yaklaşım olduğu noktasından hareketle, neoklasik iktisadın disiplinin ortodoksisini temsil ettiğinin, ancak anaakım iktisadın Neoklasik İktisattan ibaret olmadiğının ve anaakımın Neoklasik İktisat dışında başka yaklaşım ve düşünce okullarını da barındırdığının altını çizmektir.

Anahtar Kelimeler: Neoklasik İktisat, Anaakım İktisat, Ortodoks İktisat

\begin{abstract}
There are such concepts used to define neoclassical economics as 'orthodox', 'mainstream', 'conventional', 'dominant', 'modern', 'prevalent' or 'standard' in economic literature. But these concepts have different meanings. Yet if we accept that these concepts have the same meaning, the discipline of economics evolves. In this regard such concepts as 'orthodox' and 'mainstream' may change in time. So for example some school of thought which is a part of mainstream may fall outside of mainstream in future or vice versa. Similarly the orthodoxy of the discipline may change eventually. The aim of this paper, from the point of view that neoclassical economics is dominant approach in economics discipline nowadays, to emphasize that neoclassical economics represents the ortodoxy of economics discipline, but mainstream doesn't consist of only neoclassical economics and includes other approaches and schools of thought along with neoclassical economics.
\end{abstract}

Keywords: Neoclassical Economics, Mainstream Economics, Orthodox Economics

\footnotetext{
${ }^{1}$ Aksaray Üniversitesi Spor Bilimleri Fakültesi, husnubilir@aksaray.edu.tr, ORCID: 0000-0001-9602-8267
} 


\section{Giriş}

İktisadi düşüncenin en önemli veçhelerinden birisi terminolojinin sınıflandırılması ve bu terminolojiye tanımsal bir içerik sağlanmasıdır. Bu bakımdan sınıflandırma oldukça önemli ve kullanışlıdır, ancak bu sınıflandırma sırasında hangi varsayımların yapıldığı, hangi standartların seçildiği ve bu sınıflandırmayı yaratan güdülerin ne olduğu gibi sorular ön plana çıkmaktadır.

Bir tanımlama ve sınıflandırma yapılırken temel amaç kuşkusuz tanımlanmaya çalışılan kavram ve yaklaşımın temel özelliklerini ifade etmek ve/veya bu kavram ve yaklaşımların ayırt edici niteliklerini vurgulamaktır, ancak bu amaca her zaman ulaşılamamaktadır. Bu durumun iktisat literatüründeki en belirgin örneklerinden biri, neoklasik iktisadın tanımlanması meselesidir. Günümüzde neoklasik iktisat olarak nitelendirilen düşünce okulunu ifade etmek üzere 'ortodoks', 'anaakım', 'geleneksel', 'dominant', 'modern', 'geçerli' veya 'standart' gibi kavramlar kullanılmaktadır. Ancak kullanılan bu kavramlar farklı çağrışımlara -hatta 'geleneksel' ve 'modern' örneğinde olduğu gibi zit anlamlara- sahiplerdir ve bu durum bir kavram karmaşasına yol açmaktadır. Bu çerçevede literatürde 'anaakım iktisat' ve 'ortodoks iktisat' terimlerinin genellikle eş-anlamlı olarak kullanıldığı (bkz. Williamson, 2000; Lawson, 2006) ve bazı çalışmaların neoklasik iktisadı anaakım ile özdeşleştirirken, bazı çalışmaların ise neoklasik iktisadı ortodoks olarak nitelendirdiği görülmektedir. Örneğin Varoufakis'e (2012) göre neoklasik iktisadın metodolojik bireycilik, metodolojik araçsalcılık ve metodolojik denge şeklindeki meta-aksiyomları, anaakım iktisadı tasvir eden genel uygulamalardır. Benzer şekilde Lavoie (2006) ve Lee de (2011) anaakım iktisat ile neoklasik iktisadın hemen hemen aynı anlama geldiğini belirtmektedir. Diğer yandan Colander vd. (2004), Davis (2008) ve Dequech'e (2007) göre ise neoklasik iktisat günümüzde iktisat disiplininin ortodoksisini temsil etmektedir.

Literatürde anaakım iktisat ile ortodoks iktisat aynı anlamda kullanılsa da, bu iki kavram farklı içeriklere sahiptir. Buna rağmen literatürde bu terimlerin eşanlamlı olarak kullanılmasının sebebi, anaakım iktisat ve ortodoks iktisat gibi kavramların açık bir şekilde tanımlanmamasıdır. $\mathrm{Bu}$ çalışmanın amacı da neoklasik iktisat, anaakım iktisat ve ortodoks iktisat tanımlarını ele almak ve neoklasik iktisadın nitelendirilmesi konusundaki kafa karışıklığına ışık tutmaktır. Bu çerçevede, çalışmanın ikinci kısmında neoklasik iktisadın bir tanımı yapılarak, genel hatları kısaca özetlenecektir. Üçüncü kısımda ise, anaakım ve ortodoks iktisat kavramları ve bu kavramlar arasındaki ilişki ele alınacak ve neoklasik iktisadın hem disiplinin 'ortodoksi'sini temsil ettiği, hem de 'anaakım iktisat'ın bir parçası olduğu ifade edilecektir.

\section{Anaakım Iktisat ve Ortodoks íktisat Terimleri}

Anaakım iktisat, her şeyden önce, entelektüel ve sosyolojik veçheleri olan bir terimdir. Entelektüel tanım, iktisatçıların benimsedikleri veya benimsemedikleri teorik kavramlar ve/veya yöntemler üzerine inşa edilirken, sosyolojik tanım toplumsal grupların ve iletişim ağlarının üyesi olmak üzerine temellenmektedir. Entelektüel tanımlara bakıldığında, anaakım iktisadı, örneğin Colander'ın (2000) 'ad hoc modelleme', Lawson'in (1997) 'tümdegelimci', Weintraub'un (1985) ise, genel denge teorisi ilkeleri anlamında 'birleşik bir yapı' olarak tanımladığı görülmektedir. Tüm anaakım iktisatçıların paylaştığı temel varsayımların, 
maksimize edici davranış, sabit tercihler, denge ve tam bilgi olduğunu belirten Backhouse'a (2000) göre ise, anaakımın ayırt edici özelliği model geliştirmeye dayanmasıdır. Benzer şekilde, Colander vd. (2004) ve Lawson da (2006) matematiksel formalizasyon vurgusunu anaakım iktisadın ayırt edici özelliği olarak nitelendirmektedirler². Rothbard’a (1997) göre ise anaakım iktisadı bir arada tutan şey, reel dünyaya ilişkin belli varsayımlar değildir, daha ziyade pozitivist metodolojiye olan bağlliktır.

Ancak anaakım iktisadı bu şekilde belli müşterek özellikler üzerinden tanımlamak bazı sakıncalar doğurabilmektedir. İlk olarak, tüm anaakım iktisadı tanımlayacak müşterek kavram ve/veya yöntemler bulmak son derece güçtür. Örneğin anaakımın müşterek özelliklerinden birisi olarak nitelendirilen matematiksel formalizasyon vurgusu bazı heterodoks yaklaşımlar veya düşünürler tarafından da paylaşılmaktadır. Matematiksel formalizasyona vurgu yapan heterodoks iktisatçılar da bulunduğu için, bu özellik anaakım iktisadın birleştirici bir özelliği olmasına rağmen, anaakım iktisadı heterodoks iktisattan ayırt etme konusunda yetersiz kalabilmektedir ${ }^{3}$. Örneğin Backhouse ve Bateman (2011) Keynes'in çalışmalarında matematiğin önemli bir role sahip olduğunu belirtirken, Davis de (2009) Sraffacı iktisadın ve analitik Marksistlerin de matematiğin önemini vurguladıklarını ifade etmektedir. Bununla birlikte, anaakımın bir diğer müşterek özelliği olarak kabul edilen metodolojik bireycilik varsayımının da bazı heterodoks yaklaşımlar tarafından benimsendiği söylenebilir. Granovetter'in de (1992, s. 4) belirttiği gibi, psikolojik revizyonizm görüşünü benimseyen davranışsal iktisadın bu görüşü başarıya ulaşmıştır, zira anaakım iktisatçıların iktisadi eyleyenlerin atomist bir şekilde ele almalarına olanak sağlamıştır ${ }^{4}$

İkinci olarak, anaakımı entelektüel açıdan tanımlamak, belli bir dönemin anaakımını tanımlamak anlamına gelmektedir. Halbuki anaakım sürekli değişen bir yapıya sahiptir. Örneğin neoklasik iktisat terimini ilk kullanan düşünür olan Veblen, bu terimi o dönemin anaakımını tanımlamak üzere kullanmamıştır, zira o dönemin anaakımı -bilhassa ABD'dekurumsal iktisattı. Ancak kurumsal iktisadın günümüzde o dönemki etkisini yitirdiği ve anaakım iktisadın dışında kaldığı söylenebilir.

Bu nedenle anaakımı entelektüel değil sosyolojik açıdan tanımlamak daha uygun olacaktır. Zira sosyolojik tanımlar, anaakımı bir kavram ve/veya yöntem üzerinden değil, bir topluluk ve bu topluluğun iletişim ağları bağlamında ele almaktadır. Bu bakımdan sosyolojik tanımlar, Mearman'ın (2012, s. 415) belirttiği gibi, grup üyeliklerine, kültür topluluklarına, iletişim ağlarına ve bu gruplarla alakalı gücün konumuna ve uygulanmasına odaklanmaktadır. Örneğin anaakım iktisadın büyük ölçüde sosyolojik açıdan tanımlanan bir kategori olduğunu belirten Colander vd.'ne (2004, s. 490) göre anaakım “belli bir zamanda önde gelen akademik kurumlarda, organizasyonlarda ve dergilerde, bilhassa lisansüstü araştırma kurumlarında

\footnotetext{
Lawson’a (2006, s. 488-489) göre "matematikselleşme eğilimi”, yalnızca 1990 sonrası dönemin değil "son elli yılın veya daha fazlasının anaakım projesinin esas ayırt edici özelliğidir.” Lawson burada matematiksel iktisatçıların her yere uyguladıkları 'formalist-tümdengelimci çerçeve'yi kast etmekte ve anaakım iktisadı "belirli matematiksel (tümdengelimci) yöntem biçimlerine duyulan güven" ve "belirli matematiksel tümdengelimci muhakeme biçimlerine duyulan güven” üzerinden tanımlamaktadır.

${ }^{3}$ Dequech (2007, s. 290) bu noktada, matematiksel modeller inşa etmeyen ancak önemli bir saygınlığa ve etkiye sahip iki iktisatçının matematiksel formalizasyon konusunda istisna teşkil ettiklerini vurgulamaktadır: Nobel ödüllü iktisatçılar Ronald Coase ve Douglass North.

4 Dequech (2007, s. 292) bu noktada yine North'un yanı sıra, Knight ve Grief in çalışmalarını istisna olarak ele almaktadır. Backhouse'a (2004, s. 267) göre ise, Stiglitz geleneksel formel aletler kullanarak piyasa-karşıtı argümanlar geliştirmiştir; bu bakımdan Stiglitz anaakım gözükmesine rağmen bir bakıma da anaakım değildir.
} 
hâkim konumda olan bireylerin benimsediği görüşlerden; anaakım iktisat ise, mesleğin elitleri tarafından kabul edilebilir bulunan fikirlerden meydana gelmektedir ${ }^{5}$."

$\mathrm{Bu}$ tanım doğrultusunda, anaakım iktisadın bir parçası olmak için elitler grubunun bir üyesi olmaya gerek yoktur, elitlerin fikirlerini paylaşmak yeterlidir. Ancak bizzat mesleğin elitleri de bu tanım içerisine dâhil edilebilir, bu durumda anaakım iktisadın kapsamı genişleyecektir. Dequech de (2007, s. 281), bu noktadan hareketle, anaakım iktisadı daha geniş bir çerçevede ele almakta ve anaakım iktisadı "en saygın üniversitelerde ve yüksekokullarda öğretilen, en saygın dergilerde yayımlanan, en önemli araştırma vakıfları tarafından desteklenen ve en saygın ödülleri kazanan” iktisat olarak tanımlamaktadır'. Diğer bir ifadeyle, Dequech'e (1999, s. 422) göre anaakım iktisat "öğretildiği üniversitelerin ve yayımlandığı dergilerin saygınlığıyla desteklenen bir bilgi türü” olarak ele alınabilir.

Dolayısıyla Dequech (2007) anaakım iktisadı saygınlık ve etki temelinde sosyolojik açıdan tanımlamaktadır ve bu tanım, saygın üniversitelerde ve yüksekokullarda öğretilen fikirleri ve bu fikirlerin diğer, daha az saygın yerlerdeki destekçilerini de kapsaması anlamında Colander vd.'nin (2004) tanımına göre daha kapsayıcıdır . Bu bağlamda yeni fikirlerin kabul edilebilir olup olmadığını anaakım içerisindeki 'elitler' belirlemektedir, ancak burada kast edilen kişilerin kendisi değil, bu bireylerin 'benimsediği görüşler' dir. Diğer bir ifadeyle -hem Colander vd.'nin, hem de Dequech'in tanımları doğrultusunda- anaakımın seyrini belirleyen unsur, hâkim konumdaki elitlerin fikirleridir. Bizzat hâkim konumda olan elitler üzerinden değil de, onların fikirleri üzerinden anaakımı ele alan bu tanım da, anaakım iktisadın daha esnek ve geniş kapsamlı bir şekilde ele alınmasına imkân tanımaktadır, zira bir birey anaakım açısından uygun ve uygun olmayan fikirlere aynı anda sahip olabilir veya daha önce benimsemiş olduğu görüşleri -örneğin aaakıma uygun fikirleri- değiştirerek, bunların tam aksini -örneğin heterodoks olarak nitelendirilen fikirleri- benimseyebilir.

$\mathrm{Bu}$ çerçevede anaakım iktisat sosyolojik açıdan tanımlandığında, spesifik bir düşünce okulunu ifade etmemektedir. Colander vd. de (2004, s. 490) anaakım iktisadın "tarihsel olarak belirlenmiş bir okul"u değil, "dünyanın en iyi okullarında ve kurumlarında entelektüel açıdan sağlam ve çalışmaya değer olduğu düşünülen inançlar”ı tanımladığının altını çizmektedirler8. Dolayısıyla anaakım iktisat içerisinde birbirleriyle çelişen fikirler yer alabilmektedir. Dequech de (2007, s. 283) bu durumu şu sözlerle vurgulamaktadır:

\footnotetext{
5 Colander vd. (2004) burada 'elit' ile en iyi üniversitelerdeki öncü iktisatçıları kast etmekte ve elit sınıfını, geçmiş dönemde düşünceye önemli katkılar sağlamış anaakım iktisatçılar olarak tanımlamaktadır. Bu tanım Nobel ödülü kazanan bazı isimleri ve en iyi lisansüstü programlarında önde gelen makamlarda bulunan pek çok iktisatçıyı kapsamaktadır. En bilinen anaakım seçkinler arasında Paul Samuelson, Kenneth Arrow, Robert Solow, Thomas Schelling, Amartya Sen, Joseph Stiglitz, Chris Sims, Michael Woodford, George Akerlof, Richard Thaler, Anne Krueger ve Jagdish Bhagwati sayılabilir.

${ }^{6}$ Benzer şekilde Lee de (2012, s. 344-348) anaakım iktisadı sosyolojik çerçevede tanımlamakta ve anaakım iktisadın kendi dergilerine, departmanlarına ve araştırma programlarına sahip olduğunu ifade etmektedir.

Bununla birlikte anaakımın -entelektüel ve sosyolojik tanımlarının yanı sıra- psikolojik bir tanımı da bulunmaktadır ve psikolojik tanımlamada iki unsur söz konusudur: tutum ve kendini tanımlama.

${ }^{8}$ George (2007) ise anaakımın sahip olduğu bu iletişim ağlarının olumsuz yanlarına dikkat çekmektedir. George’ye (2007, s. 418-421) göre anaakım iktisatçılar sürü hayvanları gibidir ve belli uygulama mekanizmalarına sahiptirler, sözde temel dergilerdeki ve atama ve kariyer gelişimi konusundaki rolleri önemlidir. Örneğin iktisadi düşünce tarihi, metodoloji ve radikal iktisat konularında uzmanlaşan bir iktisatçının meslekte ilerlemesi nispeten zordur. Ancak anaakımın çoğulculuğa karşı çıkması bununla sınırlı değildir: İktisat alanında yayımlanan pek çok makale, halihazırda yayımlanan makalelerden çok az noktalarda farklılaşmaktadır; standart-olmayan varsayımlar benimsenmesi ve moda olan tekniklerin eleştirilmesi, makalelerin bilhassa sözde temel dergiler tarafından reddedilmesi için yeterlidir. Böylelikle anaakım homojenliğini sürdürmektedir, ancak kanıtlara değil de otoritesine başvurarak.
} 
"Sosyolojik terimler üzerinden tanımlanan anaakım iktisadın, içsel olarak tutarlı olması gerekmez; birbirleriyle çelişen fikirlerin hepsi anaakım iktisada dâhil olabilir (...) Bir düşünce okulu içsel olarak tutarlı oldukları farz edilen belli bir fikirler setiyle tanımlanabilir. Bu çerçevede, farklı düşünce okulları ve tek bir düşünce okulu haline gelemeyen fikir setleri de anaakım iktisada dâhil olabilir.”

Bu bağlamda, anaakım iktisadı sosyolojik açıdan tanımlamak, bir yandan farklı düşünce okullarının ve yaklaşımların da anaakıma dâhil olmasını sağlarken, diğer yandan anaakımın değişen ve evrilen yapısına dikkat çekmektedir. Hem mesleğin elitleri, hem de bu elitlerin fikirleri zaman içerisinde değiştiği için, anaakımın da zaman içerisinde değiştiği/değişeceği söylenebilir. Dolayısıyla bir dönem anaakım olan bir düşünce okulu veya yaklaşım, sonraki dönemlerde anaakımın dışında kalabilir veya tam tersine bugün anaakım dışında kalan bir düşünce okulu veya yaklaşım gelecekte anaakıma dâhil olabilir. Örneğin Mearman'a (2012, s. 416) göre bu durumun en güzel örneklerinden birisi Keynes'in fikirleridir. Benzer şekilde, daha önce ifade edildiği gibi, Amerika'da 1900'lü yılların başlarında kurumsal iktisat neoklasik iktisattan daha etkindi, yani neoklasik iktisat anaakım değildi.

Colander vd.'ne (2004, s. 488-489) göre de iktisat disiplininde, Lakatos’un (1978) önerdiği şekilde kümülatif evrimci değişiklikler meydana gelmektedir: Mevcut elitlerin belli üyeleri yeni fikirlere açık olmaya başladığında, bu açıklık yeni fikirlerin yayılmasına, gelişmesine ve mesleğe dâhil olmasına yol açmaktadır. Bu doğrultuda kademeli bir değişim meydana gelmekte ve bazı durumlarda kendilerini heterodoks olarak nitelendiren isimlerin fikirleri 'normalleşmekte' ve heterodoks olmaktan uzaklaşmaktadır. Böylelikle anaakım genişlemekte ve daha geniş bir yaklaşım ve anlayış yelpazesini içerecek şekilde evrilmektedir?

Ortodoks iktisat terimi ise iktisat disiplininin dogmatik ve statik kısmını ifade etmektedir. Zira ortodoks terimi değişmeyen bir düşünce geleneğine işaret etmektedir. Örneğin Paradigma Felsefe Sözlüğü'nde ortodoks "genel görüş ya da uzlaşıma uygun olan, geleneksel inançlara aykırı düşmeyen inançlar; (...) oluşturulmuş gelenek ya da çerçevenin dışına çıkan görüş veya öğretiye karşıt olarak, bir kurum ya da insan öbeği tarafından doğru bulunan ve kabul edilmesi istenen öğreti ya da görüş için kullanılan sıfat" (Cevizci, 1999, s. 651) olarak tanımlanmaktadır. Dolayısıyla ortodoksi gelenekselliği, içsel doğruluğu, tutuculuğu ve değişmeyen bir düşünce yapısını ve geleneğini ifade etmektedir.

Ancak iktisat literatüründe ortodoks terimi iktisadi düşünce tarihçileri tarafından genellikle en yakın dönemin hâkim düşünce okulunu ifade etmek üzere kullanılmaktadır ve geriye dönük bir ifade olan bu terim esasen entelektüel olarak tanımlanmaktadır. Bu çerçevede Colander vd.'ne (2004, s. 491) göre iktisat literatüründe ortodoks teriminin iki önemli veçhesi bulunmaktadır. Birincisi, ortodoks terimi veya tanımlaması, ortodoksinin var olduğu ileri sürülen zamandan sonra gelmektedir, yani ortodoksi terimi geriye-dönük bir terimdir. İkincisi, en azından iktisatta, ortodoks teriminin genellikle ortodoks fikirleri destekleyen biri tarafından değil de, ortodoks fikirlere karşı çıkan bir muhalif tarafından önerilmiş olmasıdır. Örneğin 'klasik iktisat'

\footnotetext{
9 Colander vd. (2004) ise meydana gelen değişimlerin ufak değişiklikler olduğunu ve yalnızca düşünce tarihçileri geriye dönüp baktığında daha büyük değişikliklerin göze çarpacağını ifade etmektedirler. Benzer şekilde Dequech de (2007, s. 282) anaakım iktisatta değişim faktörünün o kadar ağır basmadığını ve en saygın ve etkili lisans ders kitaplarının içeriklerinin anaakım iktisadın bir parçası olarak kabul edildiğinde, anaakım iktisattaki değişimin daha yavaş olacağını ileri sürmektedir.
} 
terimini Karl Marx (1859) ve 'neoklasik iktisat' terimini de Thorstein B. Veblen (1900) bu bakış açılarını daha kolay eleştirebilmek için kullanmışlardır.

Günümüzde iktisat literatüründe ortodoks iktisat terimiyle karşılanan düşünce geleneği ise neoklasik iktisattır, yani iktisat disiplinine en yakın dönemde hâkim olan düşünce geleneğinin neoklasik iktisat olduğu konusunda literatürde bir fikir birliği bulunmaktadır (Colander vd., 2004; Dequech, 2007; Black, Hashimzade ve Myles, 2013; Hands, 2015). Bu çerçevede Colander vd.'ne (2004, s. 490) göre neoklasik ortodoksinin belki de en önemli karakteristiği, tercih edilen metodolojik yaklaşımın aksiyomatik tümdengelim olmasıdır. Benzer şekilde Dow da (2008, s. 74) ortodoks iktisadın temel özelliğinin yalnızca tek bir metodoloji (matematiksel formalizm) benimsemesi olduğunu ileri sürmektedir. George'ye (2007, s. 417-418) göre ise ortodoksinin öne çıkan özellikleri arasında, teoriye yönelik olarak 'matematiksel model' fikrine dayanan belli bir bakış açısı barındırması ve bu çerçevede konudan ziyade tekniğe odaklanması; ekonometrik tekniklere dayanan empirik bir çalışma gerektirmesi; yalnızca sınırlı sayıdaki teorik yaklaşımı kabul etmesi ve çoğulculuğa karşı çıkması; siyaset, sosyoloji ve iktisat tarihi gibi disiplinlere karşı 'emperyalist' bir tutum takınması; ve çok sıkı bir mesleki yapıya sahip olması (örneğin, yayın yelpazesinin -sözde temel dergilerle- son derece sınırlı olması) sayılabilir. Bu bakımdan, Estey'in de (1936, s. 794) belirttiği gibi, ortodoks iktisadın geçerliliğinin, içeriğinden ziyade yönteme bağlılıktan kaynaklandığı söylenebilir. Diğer bir ifadeyle ortodoks iktisadın ayırt edici özelliği belli bir metodolojiye olan bağlılıktır ve bu bakımdan ortodoks iktisat disiplinin statik ve geleneksel yönünü temsil etmektedir.

\section{Neoklasik iktisat: Anaakım mı, Ortodoks mu?}

$\mathrm{Bu}$ çerçevede yanıt aranan soru, neoklasik iktisadın ortodoks mu yoksa anaakım mı olduğudur. Ancak neoklasik iktisadın, disiplinin anaakımını mı yoksa ortodoksisini mi temsil ettiği sorusuna yanıt vermeden evvel, neoklasik iktisadın genel hatlarıyla tanımlanması yerinde olacaktır. İktisat literatüründe sıklıkla kullanılmasına rağmen, neoklasik iktisat teriminin açık bir tanımı yapılmamıştır ve zımni olarak herkesin üzerinde görüş birliğine vardığı kabul edilmektedir. Bu nedenle neoklasik iktisat terimi, Lawson'ın da (2006, s. 486) belirttiği gibi, nadiren tanımlanan, daima yanıltıcı olan bir kategori haline gelmiştir.

Neoklasik iktisat terimi ilk olarak Veblen (1900) tarafından kullanılmıştır. Bu kavramı Marshall'ın çalışması bağlamında ele alan Veblen neoklasik iktisat terimini, bir yandan klasik geleneğin devamı niteliğinde ele alırken, diğer yandan da klasik gelenekten ayrılan bir iktisadı ifade etmek üzere kullanmaktadır. Diğer bir ifadeyle Veblen için neoklasik iktisat, ontolojik farkındalığa sahip iken bu farkındalığı kullanarak tutarsız bir metodoloji sunmaktadır. Bu bakımdan Veblen neoklasik terimini, bir geçiş kavramı olarak ele almakta ve evrimsel bilimin farkında olan ancak onun araç ve yöntemlerinden yine de evrimsel olmayan bir çıkarsama doğrultusunda yararlanan iktisat için kullanmaktadır. Dolayısıyla neoklasik iktisadın ayırt edici özelliği, Veblen için, nedensel kümülatif silsilenin farkında olması, ancak bunu evrimsel bir yöntemle ele almamasıdır. Veblen'in bu tanımını baz alarak, neoklasik iktisadı tanımlayan bazı müşterek özellikler tespit edilebilir (Bilir, 2018, s. 665-666): 
1. Evrimsel süreç dikkate alınmamaktadır, yani taksonomiktir: Neoklasik iktisatta, iktisadi analiz kurumsal ve kültürel adaptasyon ve gelişim süreci üzerinden yapılmamaktadır; yani iktisadi süreç dinamik değil, statiktir.

2. Metodolojik bireycilikten yola çıkılmaktadır: Neoklasik iktisatta tüm iktisadi (ve toplumsal) fenomenler, bireyden yola çıkılarak izah edilmektedir, yani analizin temel unsuru bireydir. Bu bakımdan, toplum da bireylerin toplulaştırılmasından oluşan pasif bir yapıdan başka bir şey değildir.

3. Bireyler rasyonel hareket etmektedir: Neoklasik iktisatta atomist bir şekilde hareket eden, çevresinden etkilenmeyen ve bu amaç doğrultusunda rasyonel davrandığı varsayılan bir homo-æconomicus yani "rasyonel iktisadi insan" anlayışı söz konusudur.

4. Fayda temelli analiz yapılmaktadır: Yapılan metodolojik bireycilik ve rasyonalite varsayımlarının -doğal- bir sonucu, neoklasik iktisatta değerin fayda temelinde tanımlanmasıdır. Neoklasik iktisatta rasyonel davranan ve kişisel-çıkarı peşinde koşan bireyin amacı faydasını maksimize etmektir.

5. Modelleme ve matematik merkezi bir öneme sahiptir: Öngörücü modeller (teoriler) oluşturma çabasında olan neoklasik iktisat, analizlerde matematiği yoğun biçimde kullanmaktadır. Zira neoklasik iktisatçılar açısından matematik önemli bir araçtır ve matematiksel yöntem de, bu amaç doğrultusunda, sistematik yani "bilimsel” yöntem olarak kabul edilmiştir.

6. Her zaman dengeye yönelim söz konusudur: Neoklasik iktisatta, ekonomide zaman içerisinde her daim dengeye yönelen bir hareket olduğu varsayılmaktadır. Yani rasyonel bireylerin kişisel-çıkarları peşinde koşmaları neticesinde iktisadi sistemde denge (Walrasyan anlamda 'genel denge', Marshallyan anlamda ise 'kısmi denge') ortaya çıkmaktadır. Bu süreçte dengesizlikler ise, dengeye yönelim sürecinde ortaya çıkan geçici durumlardır.

Dolayısıyla neoklasik iktisadın, Veblen'in tanımladığı haliyle, bir analiz yöntemi olduğu söylenebilir. Evrimsel unsurların değil de taksonomik unsurun baskın olduğu bu analiz yönteminin ön plana çıkan özelliği ise, rasyonel davrandığı ve yegâne amacının faydasını/kârını maksimize etmek olduğu kabul edilen bir birey kurgusundan yola çıkılması ve analiz esnasında matematiğin yoğun biçimde kullanılmasıdır.

$\mathrm{Bu}$ çerçevede, neoklasik iktisadın temel özelliklerinin metodolojik bireycilik ve matematiksel yönteme bağlılık olduğu dikkate alındığında, neoklasik iktisadın iktisat disiplininin ortodoksisini temsil ettiği söylenebilir. Zira, daha önce ifade edildiği gibi, ortodoksi terimi gelenekselliği ve statik bir bakış açısını ima etmektedir ve neoklasik iktisadın ön plana çıkan özelliği de, içerikten ziyade yönteme odaklanması ve neoklasik olarak adlandırılan tüm iktisatçıların bu yöntemi kullanmayı sürdürmesidir, yani metodolojik bağlılıktır. Lawson'a (2013) göre de neoklasik iktisatçllar, toplumsal realitenin tarihselliğini fark eden, ancak analiz yöntemi konusunda ısrarcı olan bir teorisyenler grubunu kapsamaktadır.

Diğer yandan -anaakım iktisadın müşterek özellikleri göz önünde bulundurulduğundaneoklasik iktisadın temel özelliklerinin metodolojik bireycilik ve matematiksel yönteme bağlılık olması, neoklasik iktisadı anaakım iktisadın da bir parçası haline getirmektedir. Bu çerçevede, 
neoklasik iktisat günümüzde anaakım iktisat içerisinde -zayıflamakla birlikte- hâlâ önemli bir nüfuza sahiptir (Davis, 2006; Dequech, 2007; Morgan, 2016). Ancak burada söylenmek istenen, neoklasik iktisadın anaakım olmadığı, anaakımın bir parçası olduğudur. Zira anaakım iktisadın yalnızca neoklasik iktisattan ibaret olmadığı ve daha çoğulcu bir yapıya sahip olduğu söylenebilir ${ }^{10}$ (Backhouse, 2000; Colander, 2000; Colander vd., 2004; Davis, 2006, 2008; Dequech, 2007; Dow, 2000, Santos, 2011). Örneğin Colander vd.'ne (2004, s. 486-488) son dönemde iktisadın kıyısında bir değişim ve çeşitlilik yaşanmaktadır ${ }^{11}$. Bu çerçevede, iktisadın kıyısında yapılan çalışmalarda, doğrusal-olmayan dinamikler gibi analitik teknolojide ve hesaplama kapasitesinde meydana gelen gelişmeler sayesinde ve diğer disiplinlerle kurulan ilişkilerin güçlenmesi sayesinde, daha önce iktisat için merkezi öneme sahip olduğu düşünülen fikirler değiştirilmekte ve genişletilmektedir.

Hands'e (2015, s. 70-71) göre ise, anaakım iktisatta yaşanan bu değişimin önemli bir göstergesi American Economic Review, Quarterly Journal of Economics, Economics Journal ve Journal of Political Economy gibi en saygın dergilerde yayımlanan makalelerin tipidir. Diğer bir önemli göstergesi de, araştırma alanlarının -emek iktisadı, çevre iktisadı, kamu maliyesi, yönetim iktisadı, uluslararası iktisat vs.- standart neoklasik fayda ve kâr maksimizasyonu çerçevesinin belli 'uygulamalar'ı olmalarıdır. Ayrıca son dönemde ele alınan konular ve tanımlanan anomaliler heterodoks iktisat geleneğinde çalışan iktisatçılar tarafindan tespit edilmiş olsa da, bu yeni alanlarda çalışan iktisatçlar kendilerini heterodoks düşünce okulu içerisinde tanımlamamaktadırlar. Dolayısıyla bu yeni çoğulcu anaakım iktisat ne neoklasiktir, ne de heterodoks.

$\mathrm{Bu}$ çerçevede neoklasik iktisat iktisat disiplininin son dönemini tanımlamak açısından yetersiz kalmaktadır. Colander'a (2000, s. 129-130) göre de, günümüzde uygulanan iktisadı tanımlamak için kullanılan neoklasik iktisat terimi yalnızca kullanışsız değildir, aynı zamanda öğrencilerin ve iktisat eğitmenlerinin çağdaş iktisadın ne olduğunu anlamalarına engel olmaktadır. 1870 yılından bu yana iktisat büyük ölçüde değişmiştir ve değişmeye devam etmektedir, bu nedenle zamanlararası bir kıyaslama yapılabilmesi için 'neoklasik iktisat' terimi miyadını doldurmuştur. Bu bağlamda Colander (2000, s. 141) modern iktisadı tanımlamak için 'Yeni Milenyum İktisadı' kavramını önermektedir'12. Benzer şekilde Lawson'a (2013) göre de 'neoklasik' terimi günümüzde orijinal anlamından uzaklaşmıştır ve artık klasik okul ile bir devamlılığa işaret

\footnotetext{
${ }^{10}$ Benzer șekilde Mearman'a (2012, s. 413) göre de anaakım iktisat homojen bir yapıya sahip değildir ve farklı gruplara sahiptir. Krugman (2009) ise 'tatlı su (yeni klasik) iktisatçıları' ile 'tuzlu su (yeni Keynesyen) iktisatçıları' arasında bir ayrım yaparak, anaakım iktisadın bazılarının düşündügü gibi tutarlı bir yapıya sahip olmadığını ileri sürmektedir. Dequech de (2007, s. 296) son yıllarda saygın dergilerde yayımlanan makalelerde belirsizlik konusunda Keynes ve Knight'a gittikçe daha fazla referans gösterildiği; sınırlı rasyonalite fikri anaakıma daha fazla dâhil olduğu; ve yeni kurumsal iktisadın önde gelen bazı saygın isimleri (örneğin North) ile 'orijinal' kurumsal iktisatçlar arasındaki kısmi anlaşmazlık nedeniyle anaakım iktisadın heterojen olduğunu ifade etmektedir. Davis'e (2008) göre ise bu yeni yaklaşımlar daha çoğulcu bir iktisattan ziyade, yeni bir ortodoksiye ve yeni bir anaakıma yol açabilir. Davis'e göre bu yeni yaklaşımların hepsi, neoklasik ortodoksiyle çelişen varsayımlara sahip oldukları için, heterodoks olarak değerlendirilmelidirler ve Davis'in bu çerçevede önerdiği terim 'anaakım heterodoks'tur.

${ }^{11}$ Colander vd. (2004, s. 492) iktisadın kıyısı ile daha önce 'ortodoks' olarak nitelendirilen fikirlere karşı çıkan çalışmaları kastetmekte ve iktisadın kıyısını, ortodoksiyi eleştiren anaakım iktisadın ve mesleğin elit sınıfı tarafından ciddiye alınan heterodoks iktisadın bir parçası olarak tanımlamaktadırlar.

${ }^{12}$ Bu çerçevede Colander’a (2000, s. 133-136) göre, neoklasik iktisadın belli veçheleri modern iktisadın bir parçası olmayı sürdürse de, modern iktisat Neoklasik İktisattan temel olarak farklıdır. Zira modern iktisat daha geniş bir dünya görüşüne sahiptir ve daha eklektiktir. Neoklasik İktisattan kopuşun kökenleri 1930'lu yıllara dek götürülebilir ve bu çerçevede modern iktisatta, kaynakların zaman içindeki dağılımına odaklanılmakta; (ders kitaplarında faydacılık kendisine yer bulsa da) pek çok modern iktisatçı faydacıllı̆ı benimsememekte; marjinal değiş-tokuştan ziyade, merkezi modelleme aracı olarak kalkülüsün yerini oyun teorisi almıştır; ileri-görüşlü rasyonalitenin yerini sınırlı rasyonaite, norm-bazlı rasyonalite ve empirik olarak belirlenen rasyonalite almıştır; kompleksite iktisatçıları, evrimci oyun teorisyenleri ve yeni kurumsal iktisatçılar metodolojik bireycilik varsayımını sorgulamaktadırlar; ve tekli dengenin yerini çoklu-denge almıştır. Bu bağlamda Colander'a (2000, s. 137-138) göre modern iktisadın tanımlayıcı özelliği içeriği değil yöntemidir, yani modellemedir; bu çerçevede 'modern iktisat model iktisadıdır'.
} 
etmemektedir ve bir içsel tutarlılık sergilemekten uzaktır; ayrıca modern iktisattaki temel gelişmeleri ve/veya yaklaşımları yansıtamadığı için de bu tür bir kavramın kullanılmasına gerek yoktur ${ }^{13}$.

Dolayısıyla günümüzde anaakımın neoklasik iktisadın yanı sıra başka düşünce okullarını ve yaklaşımları da içerdiği söylenebilir. Zira bu çalışmada anaakım iktisat sosyolojik açıdan tanımlanmakta ve neoklasik iktisadın yanı sıra, neoklasik iktisadı eleştiren muhtelif düşünce okullarının ve yaklaşımların da anaakıma dâhil olduğu kabul edilmektedir. Anaakıma dâhil olan bu yaklaşımlar belli bir saygınlığa ve nüfuza sahiptir. Bu bağlamda anaakım iktisadın homojen değil, farklı düşünce geleneklerine mensup düşünürleri bünyesinde barındıran heterojen bir yapıya sahip olduğu ve anaakım iktisat içerisindeki düşünce gelenekleri açısından ortak bir özellik tespit etmenin zor olduğu söylenebilir. Bu çerçevede günümüzde anaakım iktisat, neoklasik iktisattan ve diğer yaklaşımları içeren muhtelif düşünce okullarından oluşmaktadır. Aşağıdaki şekilde, neoklasik iktisat temelinde, iktisat disiplininin şu anki durumu gösterilmiştir.

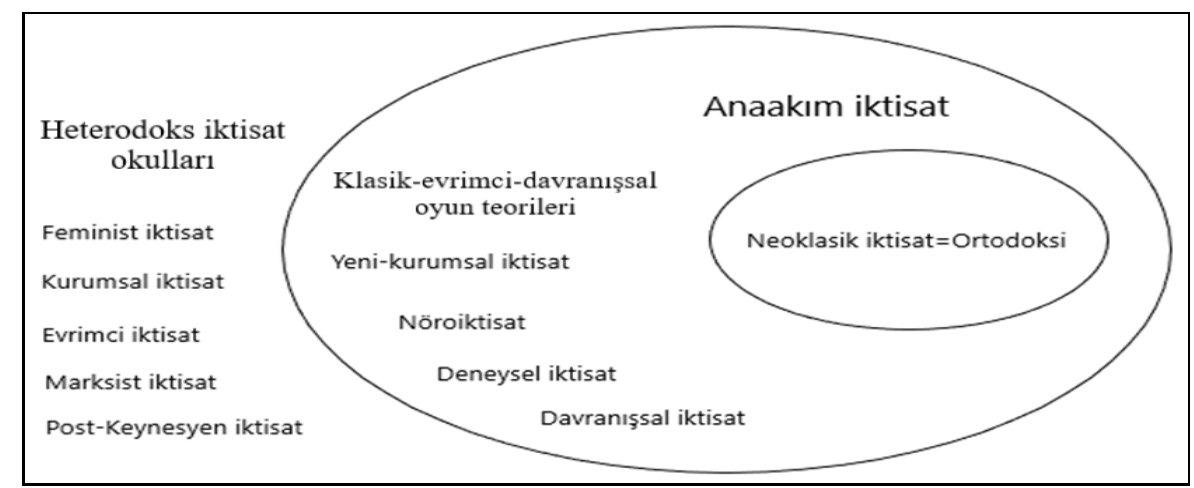

\section{Şekil 1. Iktisat Disiplininin Günümüzdeki Görünümü}

Yukarıdaki şekilde de görüldüğü üzere, iktisat disiplininin ortodoksisini günümüzde neoklasik iktisat temsil etmektedir. Zira iktisat disiplinine en yakın dönemde hâkim olan yaklaşım neoklasik iktisattır. Dünyanın önde gelen pek çok üniversitesinde neoklasik iktisat temelinde bir iktisat eğitimi verilmekte, önde gelen dergilerde neoklasik iktisadın metodolojisine uygun makaleler yayınlanmakta ve Nobel Ödülleri'nin büyük çoğunluğu Neoklasik İktisat geleneğinden gelen iktisatçlara verilmektedir. Dolayısıyla temel özelliği, birey ve fayda temelli bir analiz yapması ve bu analiz esnasında matematiksel yöntemin kullanımına sıkıca tutunması olan neoklasik iktisadın, içsel doğruluğu ve tutarlılığı ifade eden ortodoksinin iktisat disiplinindeki temsilcisi olduğu söylenebilir.

\footnotetext{
${ }^{13}$ Lee ve Keen'e (2004) göre ise anaakım iktisat teorisi hâlâ belirgin biçimde neoklasiktir. Woff ve Resnick (2012) ile Madra (2016) ise neoklasik teorinin evrilirken ele aldığı yeni konulara temel yaklaşımını uygulamaya devam ettiğini, yani yaşanan son dönem gelişmelerin temel neoklasik çerçeve içinde kaldığını belirtmekte ve iktisatta son dönemde yaşanan gelişmeleri 'geç neoklasik iktisat' olarak nitelendirmektedirler. Benzer şekilde Boettke, Leeson ve Smith de (2008, s. 14) ise, iktisadın son 20-30 ylllk dönemde büyük bir evrim geçirdiğini, ancak değişen șeyin iktisadi prensipler değil de, iktisatçlların bu prensipleri uygulama şekleri olduğunu belirtmektedirler.
} 
Diğer yandan, ortodoksiye göre daha geniş bir kavram olan anaakım iktisat içerisinde neoklasik iktisadı -bilhassa fayda maksimizasyonu temelinde- eleştiren düşünce okulları da yer almaktadır ${ }^{14}$. Bu çerçevede anaakım iktisadın neoklasik olmayan temsilcileri arasında klasikevrimci-davranışsal oyun teorileri, davranışsal iktisat, deneysel iktisat, nöroiktisat ve yenikurumsal iktisat gösterilebilir ${ }^{15}$ (Colander, 2005, 2007; Davis, 2006; Dequech, 2007).

$\mathrm{Bu}$ yeni yaklaşımlar arasında en ön plana çıkanı kuşkusuz davranışsal iktisattır. Dequech'in (2007, s. 286-287) belirttiği gibi, neoklasik iktisada fayda maksimizayonu temelinde eleştiriler sunan davranışsal iktisadın ismi, 1978 yılında Herbert Simon'un ve 2002 yılında Daniel Kahneman'in Nobel iktisat ödüllerini ve Mathew Rabin'in de 2001 yilında John Bates Clark Madalyası ${ }^{16}$ 'nı kazanmasıyla sık sık zikredilmeye başlanmıştır. Benzer şekilde, neoklasik iktisada yine fayda maksimizasyonu temelinde eleştiriler sunan deneysel iktisat da, 2002 yılında Nobel iktisat ödülünü Kahneman ile paylaşan Vernon Smith'in öncülerinden olduğu bir yaklaşımdır ve literatürde sıklıkla atıf yapılmaktadır. Kökenleri davranışsal ve deneysel iktisada dayanan nöroiktisat da (önde gelen isimleri arasında Paul Glimcher, Colin Camerer, Paul Zak ve Kevin McCabe sayılabilir), son yıllarda saygın akademik dergilerde ve popüler basında kendisine gittikçe daha fazla yer bulmakta ve kendisine ait toplulukları kurulmaktadır ${ }^{17}$ (Bilir, 2017, s. 128). Douglas North ve Oliver Williamson'ın çalışmalarıyla birlikte anılan ve neoklasik iktisada eleştiriler sunan yeni kurumsal iktisat da iyi bir saygınlığa sahiptir. Sınırlı rasyonalite varsayımıyla, neoklasik iktisadın fayda maksimizasyonu varsayımını yumuşatan ve anaakım iktisadın bir parçası haline gelen bir diğer yaklaşım da H. Peyton Young’ın önde gelen temsilcisi olduğu evrimci oyun teorisidir. Davranışsal iktisadın, deneysel iktisadın ve nöroiktisadın bu çalışmada anaakım içerisinde değerlendirilmesinin sebebi, hem -davranışsal ve deneysel iktisat örneklerinde olduğu gibi- Nobel İktisat Ödülü kazanmaları, hem de iktisat alanının en üst düzey dergilerinde kendilerine daha sık yer bulmalarıdır ${ }^{18}$ (bkz. Kelly ve Bruestle, 2011; Hamermesh, 2013).

14 Colander vd.'ne (2004, s. 492-493) göre ise modern anaakım iktisat, mevcut ortodoks yaklaşımın güçlü yanlarını dikkatli bir şekilde anlayarak yapıldıkça ve anaakım açısından kabul edilebilir modelleme metodolojisiyle yapıldıkça yeni yaklaşımlara açıtır. Bu çerçevede, mevcut elitler yeni fikirler söz konusu olduğunda nispeten daha açık-görüşlüdürler, ancak mevzu alternatif metodolojiler olduğunda oldukça kapalı-görüşlüdürler. Onlara göre modellenmezse, iktisat değildir. Dolayısıyla anaakım iktisat-heterodoks iktisat ayrımı, mesleğin kıyısında çalışıp çalışmadıklarından daha az önemlidir. Bu durumda, hem anaakım hem de heterodoks iktisatçllar neoklasik ortodoksiye karşı çıkan konular üzerinde çalışmaktadırlar. Bu çerçevede, Colander’a (2000, s. 136-137) göre David Romer, Buz Brock, Richard Thaler, William Baumol, George Akerlof, Joseph Stiglitz, David Card, Alan Krueger, Paul Krugman, Ken Arrow, Amartya Sen, Thomas Shelling gibi modern iktisatçllar neoklasik çerçevenin dışında işler yapmalarına rağmen, anaakım iktisatçılar arasında yer almaktadırlar.

15 Davis'e (2006) göre daha önce heterodoks olduğu düşünülen bazı kavramlar -örneğin kurumsal vurgular- günümüzde artık anaakıma dâhil olmuştur. Colander'a (2007) göre ise, son yıllarda anaakım iktisada dâhil olan ve uzun yıllar boyunca heterodoks iktisatçılar tarafından savunulan bu fikirler, anaakıma heterodoks iktisat vasıtasıyla dâhil olmamıştır. Örneğin post-Keynesyen iktisatçılar tarafindan vurgulanan belirsizlik unsurunu ifade edecek analitik araçlar yakın döneme dek geliştirilemediği için post-Keynesyen iktisat anaakımın dışında kalmıştır; ancak son dönemde matematik alanında kompleksite aletlerinin gelişmesiyle birlikte bu fikirler, post-Keynesyen iktisatçılara hiçbir atıf yapılmdan anaakım iktisada dâhil edilmiştir. Benzer şekilde, kurumsal iktisatçılar tarafından vurgulanan sosyo-ekonomik unsurlar ve kurumsal etkiler de, evrimci oyun teorisinin gelişimiyle birlikte anaakıma dâhil olmuş, ancak yine kurumsal iktisatçıların isimleri hiç anılmamıştır.

16 American Economic Association tarafından 40 yaşın altındaki iktisatçılara verilen son derece saygın bir ödül. Bu ödülü kazanan iktisatçıların çoğu Nobel iktisat ödülünü de kazanmışlardır.

17 Örneğin, Neuron (2002), Games and Economic Behavior (2005), Economics ve Philosophy (2008), Philosophical Transactions of the Royal Society B (2008) ve Journal of Economic Methodology (2010) gibi dergilerin nöroiktisat özel sayıları yayımlanmıştır. Benzer şekilde The Wall Street Journal, The Economist, Newsweek, Forbes ve The New York Tİmes gibi gazete ve dergilerde nöroiktisatla ilgili makale ve yazllara yer verilmektedir.

18 Bazı çalışmalarda ise bu yaklaşımlar neoklasik düşünce geleneğinden tam olarak ayrışmamaları bağlamında anaakım iktisadın bir parçası olarak ele alınmaktadır. Bu çalışmalar için bkz. Rabin, 2002; Sent, 2004; Heukelom, 2014. Benzer şekilde Lawson'a (2006, s. 491-492) göre de tüm bu yeni yaklaşımlar matematiksel-tümdengelimci modelleme konusunda ısrarcıdırlar. 
Post-Keynesyen iktisat, Marksist iktisat, evrimci iktisat, kurumsal iktisat ve feminist iktisat gibi düşünce okulları ise, heterodoks iktisat okulları olarak değerlendirilmiş ve anaakımın dişında bırakılmıştır. $\mathrm{Bu}$ düşünce okullarının da kendilerine ait dergileri ve düşünce toplulukları bulunmaktadır, ancak bu düşünce topluluklarının sahip olduğu güç ve iletişim ağları, anaakım olacak kadar güçlü değildir. Dolayısıyla anaakıma bir alternatif teşkil ettikleri için bu düşünce okulları anaakım iktisat içerisinde değerlendirilmemiştir ${ }^{19}$. Benzer şekilde American Economic Association'ın Journal of Economic Literature (JEL) sinıflandırmasına göre de, mevcut heterodoks iktisat okulları arasında sosyalist okul, Marksist okul, Sraffacı okul, tarihçi okul, kurumsal okul, evrimci okul, Avusturya okulu, feminist iktisat ve sosyal iktisat yer almaktadır (https://www.aeaweb.org/econlit/jelCodes.php?view=jel\#B).

\section{Sonuç}

İktisat literatüründe neoklasik iktisadı nitelemek üzere 'ortodoks', 'anaakım', 'geleneksel', 'dominant', 'modern', 'geçerli' veya 'standart' gibi kavramlar kullanılmaktadır. Literatürde en sık kullanılan tanımlamalar ise 'anaakım' ve 'ortodoks' iktisattır. Ancak bu iki terim farklı anlamlara sahiptir ve bu durum da bir kavram karmaşasına yol açmaktadır.

$\mathrm{Bu}$ çerçevede anaakım ve ortodoks iktisat terimlerinden önce neoklasik iktisadın tanımlanması hangi kavramın daha uygun olacağının belirlenmesi açısından yararlı olacaktır. İlk olarak Veblen (1900) tarafından kullanılan neoklasik iktisat terimi spesifik ve tarihsel bir oluşumdur ve bir analiz biçimini veya yöntemi tarif ettiği söylenebilir. Zira neoklasik iktisat evrimsel süreçleri dikkate almayan ve taksonomik bir bakış açısından hareket eden ve bu doğrultuda metodolojik bireycilik varsayımını belirleyen, bireylerin fayda temelli rasyonel hareket ettiklerini kabul eden, modelleme ve matematiğin merkezi bir öneme sahip olduğu ve her zaman dengeye yönelimin söz konusu olduğu bir yaklaşımı ifade etmektedir. Evrimsel unsurların değil de taksonomik unsurun baskın olduğu bu analiz yönteminin ön plana çıkan özelliği ise, birey ve fayda temelli bir analiz yapması ve bu analiz esnasında matematiği yoğun biçimde kullanmasıdır.

Sosyolojik ve entelektüel açılardan tanımlanabilen anaakım iktisat ise, mantıklı ve çalışmaya değer olan görüşleri kapsayan, eklektik ve geniş bir yapıyı ifade etmektedir. Ancak entelektüel tanımda olduğu gibi anaakımı belli bir kavram ve/veya yöntem üzerinden tanımlanan statik ve değişmeyen bir yapı olarak telakki etmek yanlış olacaktır. Anaakımı sosyolojik açıdan tanımlamak, hem bu kavramın iktisadi düşünce tarihinin her dönemine uygulanabilmesini sağlamakta, hem de anaakımı neoklasik iktisat ile kısıtlamamakta ve neoklasik iktisadı eleştiren farklı düşünce okulu veya yaklaşımların da anaakım içerisinde yer almasına olanak tanımaktadır.

\footnotetext{
${ }^{19}$ Bu düşüncenin aksini savunan çalışmalar da söz konusudur. Örneğin Mearman’a (2012, s. 411) göre feminist iktisatçılar bilhassa İngiltere ve Avrupa'da heterodoks toplumsal grupların nispeten daha az parçası olmuşlardır; Feminist Economics (Feminist İktisat) dergisi anaakım değerlendirmelerde yüksek sıralamaya sahiptir.
} 
Ortodoksi ise sabit kalan, dinamiğe, değişime ayak uyduramayan bir yapıyı işaret etmektedir. İktisat literatüründe ise, iktisadi düşünce tarihçileri ortodoksiyi genellikle disipline en yakın dönemde hâkim olan düşünce okulunu ifade etmek üzere kullanmaktadır. Bu nedenle iktisat disiplinine günümüzde hâkim olan neoklasik iktisat, iktisat disiplininin ortodoksisini temsil etmektedir. Bu durumun en net ifadesi ise, neoklasik iktisatçların bireysel, fayda temelli ve matematiksel analiz yöntemine olan bağılıklarıdır. Dolayısıyla neoklasik iktisadın, disiplinin statik ve geleneksel yönünü yansıtmaktadır.

Diğer yandan neoklasik iktisat anaakım iktisadın da bir parçasıdır, ancak anaakım iktisat sadece neoklasik iktisattan ibaret değildir ve neoklasik iktisat dışındaki yaklaşımları da içermektedir. Örneğin klasik-evrimci-davranışsal oyun teorileri, davranışsal iktisat, deneysel iktisat, nöroiktisat ve yeni-kurumsal iktisat anaakım iktisadın neoklasik iktisat dışındaki üyeleri arasında yer almaktadır. Bu yaklaşımların anaakım olarak nitelendirilmelerinin sebebi ise, hem -davranışsal ve deneysel iktisat örneklerinde olduğu gibi- Nobel İktisat Ödülü kazanmaları, hem de iktisat alanının en üst düzey dergilerinde kendilerine daha sık yer bulmalarıdır.

Kendilerine ait dergileri ve düşünce toplulukları bulunan ancak bu düşünce topluluklarının sahip olduğu güç ve iletişim ağları, anaakım olacak kadar güçlü olmayan Post-Keynesyen iktisat, Marksist iktisat, evrimci iktisat, kurumsal iktisat ve feminist iktisat gibi düşünce okulları ise, anaakımın dışında kalmaktadır.

Kısacası neoklasik iktisat günümüzde bir yandan iktisat disiplininin ortodoksisini temsil ederken, diğer yandan anaakım iktisadın da bir parçasıdır. Anaakım iktisat içerisindeki baskın rolünün azalmakta olduğu söylenebilse de, yine de neoklasik iktisadın anaakım üzerindeki hâkimiyeti sürmektedir. Ancak bu durumun tarihsel sürecin bir parçası olduğu unutulmamalıdır. $\mathrm{Bu}$ nedenle, neoklasik iktisat gelecek dönemde hem ortodoksiyi temsil etmekte uzaklaşabilir, hem de anaakım iktisadın dışında kalabilir. Dolayısıyla burada söylenmek istenen, elbette neoklasik iktisadın 'ortodoks' ya da 'anaakım' olabileceği, ancak bunun her zaman geçerli olmak zorunda olmadığıdır. Zira iktisat disiplini evrilen ve değişen bir yapıya sahiptir. Bu nedenle geçmişte heterodoks olarak nitelendirilen bir düşünce okulu veya yaklaşım bugün anaakım veya ortodoks haline gelebilmektedir veya bugün ortodoks olan bir yaklaşım veya düşünce okulu gelecekte heterodoks okul haline gelebilir. Ayrıca bir iktisatçı da ortodoksiden heterodoksiye geçebilmektedir veya ortodoksiden çıksa bile anaakım içinde kalabimektedir. $\mathrm{Bu}$ nedenle ortodoks, anaakım ve heterodoks tanımlamaları ve sınıflandırmaları değişen ve dinamik iktisat disiplinini tarif etmek açısından yetersiz ve kısıtlayıcı kalmaktadır. Bu tanımlamaların genel-geçer olmadıkları ve tarihsel süreç içerisinde değişikliğe uğrayabilecekleri vurgulanmalıdır. 


\section{Kaynakça}

Backhouse, R. E. (2000). Austrian economics and the mainstream: View from the boundary. The Quarterly Journal of Austrian Economics, 3 (2), 31-43.

Backhouse, R. E. \& Bateman, B. W. (2011). Capitalist Revolutionary: John Maynard Keynes. New York: Harvard University.

Bilir, H. (2017). Nöroiktisat: Neoklasik İktisadın Yenilenen Yüzü mü, Eleştirel Bir Yaklaşım mı? (Yayınlanmamış doktora tezi). Gazi Üniversitesi/Sosyal Bilimler Enstitüsü, Ankara.

Bilir, H. (2018). Neoklasik İktisadın Tanımlanmasına Yönelik Bir Deneme. İnsan ve Toplum Bilimleri Araştırmaları Dergisi, 7 (2), 658-670.

Black, J., Hashimzade, N. \& Myles, G. (2013). A Dictionary of Economics. Oxford: Oxford University.

Boettke, P. J., Leeson, P. T. \& Smith, D. J. (2008). The evolution of economics: Where we are and how we got here. The Long Term View, 7 (1), 14-22.

Cevizci, A. (1999). Paradigma Felsefe Sözlü̆̆̈̈ (3. Baskı). İstanbul: Paradigma.

Colander, D. (2000). The death of neoclassical economics. Journal of the History of Economic Thought, 22 (2), 127-143.

Colander, D. (2005). The future of economics: The appropriately educated in pursuit of the knowable. Cambridge Journal of Economics, 29 (6), 927-941.

Colander, D. (2007). Pluralism and Heterodox Economics: Suggestions for an 'Inside the Mainstream' Heterodoxy. Middlebury College Economics Discussion Paper, No: 07-24.

Colander, D., Holt, R. \& Rosser Jr., B. (2004). The changing face of mainstream economics. Reviews of Political Economy, 16 (4), 485-499.

Davis, J. B. (2006). The turn in economics: neoclassical dominance to mainstream pluralism. Journal of Institutional Economics, 2 (1), 1-20.

Davis, J. B. (2008). The turn in recent economics and return of orthodoxy. Cambridge Journal of Economics, 32 (3), 349-366.

Davis, J. B. (2009). The Nature of Heterodox Economics. Edward Fullbrook (Ed.), Ontology and Economics: Tony Lawson and His Critics içinde (s. 83-92). London: Routledge.

Dequech, D. (1999). Expectations and confidence under uncertainty. Journal of Post Keynesian Economics, 21 (3), 415-430.

Dequech, D. (2007). Neoclassical, mainstream, orthodox and heterodox economics. Journal of Post Keynesian Economics, 30 (2), 279-302. 
Dow, S. C. (2000). Prospects for the progress in heterodox economics. Journal of the History of Economic Thought, 22 (2), 157-170.

Dow, S. C. (2008). Plurality in orthodox and heterodox economics. Journal of Philosophical Economics, 1 (2), 73-96.

Estey, J. A. (1936). Orthodox economic theory: A defense. Journal of Political Economy, 44 (6), 791-802.

George, D. A. R. (2007). Consolations for the economist: The future of economic orthodoxy. Journal of Economic Surveys, 21 (3), 417-425.

Granovetter, M. (1992). Economic institutions as social constructions: A framework for analysis. Acta Sociologica, 35 (1), 3-11.

Hamermersh, D. (2013). Six decades of top economic publishing. who and how? Journal of Economic Literature, 51, 162-172.

Hands, D. W. (2015). Orthodox and heterodox economics in recent economic methodology. Erasmus Journal for Philosophy and Economics, 8 (1), 61-81.

Heukelom, F. (2014). Mainstreaming behavioral economics. Journal of Economic Methodology, $21(1), 92-95$.

Kelly, M. \& Bruestle, S. (2011). Trends of subjects published in economic journal 1969-2007. Economic Inquiry, 49, 658-673.

Krugman, P. (2009). How did economists get it so wrong? http://www.nytimes.com/2009/09/06/magazine/06Economic-t.html, (07.02.2018).

Lavoie, M. (2006). Do heterodox theories have anything in common: A post-Keynesian poitn of view. European Journal of Economics and Economic Policies: Intervention, 3 (1), 87 112.

Lawson, T. (1997). Economics and Reality. London: Routledge.

Lawson, T. (2006). The nature of heterodox economics. Cambridge Journal of Economics, 30 (4), 483-505.

Lawson, T. (2013). What is this 'school' called neoclassical economics? Cambridge Journal of Economics, 37 (5), 947-983.

Lee, F. S. (2011). A note on the pluralism debate in economics. Review of Radical Political Economics, 43 (4), 540-551.

Lee, F. S. (2012). Heterodox economics and its critics. Review of Political Economy, 24 (2), 337 351. 
Lee, F. S. \& Keen, S. (2004). The incoherent emperor: A heterodox critique of neoclassical microeconomic theory. Review of Social Economy, 62 (2), 169-199.

Madra, Y. M. (2016). Late Neoclassical Economics: The Restoration of Theoretical Humanism in Contemporary Economic Theory. London and New York: Routledge.

Marx, K. (1859). A Contribution to the Critique of Political Economy. Moscow: Progress.

Mearman, A. (2012). 'Heterodox economics' and the problems of classification. Journal of Economic Methodology, 19 (4), 407-424.

Morgan, J. (2016). Introduction: The Meaning and Significance of Neoclassical Economics. Jamie Morgan (Ed.), What is Neoclassical Economics? Debating the Origins, Meaning and Significance içinde (s. 1-29). London and New York: Routledge.

Rabin, M. (2002). A perspective on psychology and economics. European Economic Review, 46 (4), 657-685.

Rothbard, M. N. (1997). The Logic of Action: Method, Money and the Austrian School. Cheltenham: Edward Elgar.

Santos, A. C. (2011). Behavioural and experimental economics: Are they really transforming economics? Cambridge Journal of Economics, 35 (4), 705-728.

Sent, E. M. (2004). Behavioral economics: How psychology made its (limited) way back into economics. History of Political Economy, 36 (4), 735-760.

Varoufakis, Y. (2012). A most peculiar failure on the dynamic mechanism by which the inescapable theoretical failures of neoclassical economics reinforce its dominance. https://varoufakis.files.wordpress.com/2012/04/neoclassical-economics-as-a-mostpeculiarfailure.pdf, (22.11.2017).

Veblen, T. B. (1900). The preconceptions of economic science III. The Quarterly Journal of Economics, 14 (2), 240-269.

Weintraub, E. R. (1985). General Equilibrium Analysis. Cambridge: Cambridge University.

Williamson, O. E. (2000). The new institutional economics: Taking stock, looking ahead. Journal of Economic Literature, 38, 595-613.

Wolff, R. D. \& Resnick, S. A. (2012). Contending Economic Theories: Neoclassical, Keynesian, and Marxian. Cambridge and London: The MIT. 